\title{
Fanconi Anemia Group J Protein
}

National Cancer Institute

\section{Source}

National Cancer Institute. Fanconi Anemia Group J Protein. NCI Thesaurus. Code C63528.

Fanconi anemia group J protein (1249 aa, $141 \mathrm{kDa}$ ) is encoded by the human BRIP1 gene. This protein is involved in DNA-dependent ATPase activity, 5' to 3' DNA helicase activity, and homologous recombination. 